\title{
INCIDENCE OF SORE THROAT FOLLOWING ENDOTRACHEAL INTUBATION
}

\section{Charles J Hartsell, md, and C R Stephen, M d *}

From tIME To TIME during a busy anaesthesic practice, periods are observed during which a large number of people seem to develop sore throat postoperatively It was during such a period that we decided to investigate in an objective manner the incidence of sore throat following general anaesthesia

In reviewing the literature, few papers were found relating to this problem In 1950, Wylie ${ }^{1}$ found in a series of 100 patients that 70 per cent complained of sore throat upon direct questioning In 1951, Baron and Kohlmoos, ${ }^{2}$ two otolaryngologists, reported that everyone in a series of 80 patients complained of a mild sore throat lasting at least 24 hours following endotracheal intubation In 1958, Wolfson, ${ }^{3}$ in a review of 521 patients, found that 184 per cent complaned of sore throat when questioned directly In 1960, Conway and his group ${ }^{4}$ found in 642 patients that the incidence of sore throat was 382 per cent when the patients were questioned durectly

During the discussion of how to collect the data for our study, perhaps the most debatable question involved the manner in which patients were to be interviewed Of the papers pieviously mentioned, only one author was concerned with the method of interviewing the patient Wolfson found that 10 per cent of his patients complained spontaneously of a sore throat following intubation, whereas upon direct questioning this figure rose to 184 per cent It was decided in our study to question patients only indirectly, but to give them full scope to air all their complaints at the time of interview A minimum of five minutes was spent with each patient and the trend of questioning was somewhat as noted in Table I

\section{METHOD}

The interview was conducted 24 to 48 hours after suigery by a resident anaesthesiologist unaware of the specific factors relating to the endotracheal intubation $\mathrm{He}$ began the interview with an enquiry about the general well-being of the patient Depending upon the patient's response, further questions of a general nature were asked, concentrating primarily on any pain, soreness, or discomfort in any area of the body Every opportunity was given the patient to complain of a sore throat, should it exist Actually, a sore throat was rarely a primary complaint Some interviews were quite lengthy because multiple complaints were discussed, but an interview was never terminated unless it was believed that all complaints had been elicited

A total of 500 patients weie interviewed postoperatively 400 were exposed to

'Division of Anaesthesia, Duke University Medical Center, Durham, North Carolina 
TABLE I

Design OF INTERY IeW

\begin{tabular}{|c|c|c|c|}
\hline Initial question & Answer & Question & Answer \\
\hline & Fine - & $\begin{array}{l}\text { Do you have iny } \\
\text { pain or discomfoit? }\end{array}$ & $\begin{array}{l}\longrightarrow \text { None } \\
\longrightarrow \text { Sore thrott } \\
\longrightarrow \text { Nausca }\end{array}$ \\
\hline $\begin{array}{l}\text { How are } \\
\text { youfceling } \\
\text { today? }\end{array}$ & $\begin{array}{l}\text { Pan at } \\
\text { operative } \\
\text { site }\end{array}$ & $\begin{array}{l}\text { Do you have any } \\
\text { pun or discomfort } \\
\text { llsew here? }\end{array}$ & $\begin{aligned} \longrightarrow & \text { Vone } \\
\longrightarrow & \text { Sole throat } \\
\longrightarrow & \text { Vausca }\end{aligned}$ \\
\hline
\end{tabular}

TABLE II

Intubation D.hTa Form

\begin{tabular}{|c|c|c|c|c|}
\hline Date & \multicolumn{2}{|l|}{ Sex } & \multicolumn{2}{|l|}{ Hist No } \\
\hline Age & \multicolumn{2}{|l|}{ Race } & \multicolumn{2}{|l|}{ Ward } \\
\hline Name & \multicolumn{2}{|l|}{ Preop Drag } & \multicolumn{2}{|c|}{ Anaesthesiologisit } \\
\hline Levine Tube & \multirow{5}{*}{$\begin{array}{l}\text { Yes } \\
\text { All Upper } \\
\text { Yes } \\
\text { les } \\
\text { Ethyl Ether } \\
\text { Pentothal }\end{array}$} & No & \multirow{5}{*}{ Vone } & \multirow{6}{*}{$\begin{array}{l}\text { Other } \\
\text { Short neck, } \\
\text { stuff neck, } \\
\text { small mouth, } \\
\text { bleeding, } \\
\text { extubation with } \\
\text { full cuff, etc }\end{array}$} \\
\hline Teeth Present & & Lowe1 & & \\
\hline Nasal Arrway & & No & & \\
\hline Oropharyngeal Airway & & No & & \\
\hline Primary Agent & & $\begin{array}{l}\text { Cyclopropane } \\
\text { Fluathane }\end{array}$ & & \\
\hline Position & $\begin{array}{l}\text { Supine } \\
\text { Lithotomy }\end{array}$ & $\begin{array}{l}\text { Lateral } \\
\text { Sitting }\end{array}$ & $\begin{array}{l}\text { Prone } \\
\text { Other }\end{array}$ & \\
\hline Intubated & Yes & No & \multirow{16}{*}{ Rubber } & \multirow{17}{*}{ Commenis } \\
\hline Muscle Relaxant & \multirow{2}{*}{\multicolumn{2}{|c|}{$\begin{array}{l}\text { les } \quad \text { No } \\
\text { Wis-Foregger, Eversole, } \\
\text { Guedel, Miller, Macintosh, } \\
\text { Other }\end{array}$}} & & \\
\hline Scope Blade & & & & \\
\hline Topical & Yes & & \\
\hline Topical Technique & $\begin{array}{l}\text { Atomizer } \\
\text { Transtracheal, }\end{array}$ & $\begin{array}{l}\text { Jack Spray } \\
\text { Swab }\end{array}$ & & \\
\hline Attempts to Intubate & \multicolumn{2}{|l|}{1234} & & \\
\hline Intubation was & \multicolumn{2}{|c|}{ Easy $\quad$ Difficult } & & \\
\hline Tube Size & $\begin{array}{llll}6 & 7 & 8 & 9\end{array}$ & 10 & & \\
\hline Type Tube & $\begin{array}{l}\text { Portex } \\
\text { Other }\end{array}$ & Davol & & \\
\hline Cuff & Yes & No & & \\
\hline No c c's to inflate cuff & 123 & 4567 & & \\
\hline Pack & Yes & No & & \\
\hline Bucking at Intubation & Yes & No & & \\
\hline Bucking durng Maintenance & Yes & No & & \\
\hline Bucking at Aspiration & Yes & No & & \\
\hline Bucking at Extubation & Yes & No & & \\
\hline Duration Tube in Place & 12 & 34 hours & & \\
\hline
\end{tabular}


endotracheal intubation and 100 were anaesthetized by mask Patients under 15 years of age and those undergoing operations about the head and neck were excluded A diversity of anaesthetic drugs was utilized for operations which lasted from 30 minutes to more than four hours Intubations were performed by first and second-year residents in anaesthesia

Durng the course of anaesthesid a data form was completed, which is illustrated in Table II The form was designed in as simple a manner as possible to facilitate completion Among the factors noted specifically were presence of nasogastric tube, status of teeth, utillzation of nasal and oropharyngeal aurways. primary anaesthetic drug, position of patient, muscle relaxant employed, laryn goscope blade used, and employment of topical anaesthetic

Bucking during intubation, maintenance, aspiration, and extubation were of special interest A space for other comments or factors bearnng upon the intuba tion was included

The interview with the patient was recoided on the opposite side of the datat form, but the interviewer did not consult the data form prior to talking with the patient The patients' throats were not examined and the severity of soreness was not classified

\section{Results}

Table III shows the over-all incidence of sore throat of the 400 patients who were intubated, 23 complaned of sore throat, in the 100 patients who were not intubated, 2 developed sore throat These figures are not statistically significant, although they compare favourably with previous investigations

TABLE III

INTUBATION AND SORE THROAT

\begin{tabular}{lcc}
\hline & $\begin{array}{c}\text { Total } \\
\text { patuents }\end{array}$ & $\begin{array}{c}\text { Sore } \\
\text { throat }\end{array}$ \\
\hline Intubated & 400 & $23(57 \%)$ \\
Not intubated & 100 & $(20 \%)$ \\
\hline
\end{tabular}

The sex of a patient may have some bearming on the development of sore throat Wolfson ${ }^{3}$ found that the incidence in females was almost twice that in males, but Conway found no difference In our senes, the complaint of sore throat was noted three tumes more frequently in femalles than in males (Table IV) One explanation may be the tendency to introduce too large an endotra-

TABLE IV

INCIDENCE OF SORE THROAT BY SEX

\begin{tabular}{lccc}
\hline & $\begin{array}{c}\text { Total } \\
\text { pataents }\end{array}$ & $\begin{array}{c}\text { Sore } \\
\text { throat }\end{array}$ & \\
\hline Fernales & 104 & $12(115 \%)$ & $p<005$ \\
Males & 296 & $11(37 \%)$ & \\
\hline
\end{tabular}


cheal tube into the smaller female larynx Our study showed that some females were intubated with No 10 tubes, many with No 9 tubes, and only a few with No 8 tubes In contrast, no males received a tube larger than No 10 It is therefore possible that females were intubated with relatuvely ughter fittng tubes than males

A nasogastric tube constitutes a foreign body which usually remains in place much longer than an endotracheal tube Conway found that sore throat occurred twice as often in patients in whom a na'ogastric tube was utilized Others have not investigated this aspect of the problem In this group, the incidence of sore throat also was doubled when a nasogastric tube was employed (Table V)

TABLE $V$

\begin{tabular}{l|cc}
\multicolumn{2}{c}{ Nasogastric Tube } & and SORe Throat \\
\hline & Total & Sore \\
patients & throat \\
\hline Nasogastric tube & 223 & $17(76 \%)$ \\
No nasogastric tube & 177 & $6(33 \%)$ \\
\hline
\end{tabular}

However, we recently studied a small series of patients who were anaesthetized by mask only, with nasogastric tubes in place, and found no complaints of sore throat From our results, it is difficult to assess the role of an indwelling nasogastric tube as an aetological factor in postoperative sore throat

Trauma at the time of intubation often is believed to be related to the development of sore throat Trauma may be produced by laryngoscopy or by manipulation of the endotracheal tube in difficult intubations Previous investigators have found that trauma or difficult intubation is not associated with a higher incidence of sore throat We considered an intubation atraumatic if it was performed deftly and with ease Intubation was considered traumatic if multiple attempts were required, bleeding was noted, or if some degree of force was required with either the laryngoscope or the endotracheal tube Stlettes were not used to facilitate intubation Our findings were in keeping with those of other investigators, namely, that traumatic intubation did not increase the incidence of sore thioat significantlv (Table VI)

\begin{tabular}{lcc}
\multicolumn{3}{c}{ TABLE VI } \\
Tracma AND Sore Throat \\
\hline & $\begin{array}{c}\text { Total } \\
\text { patients }\end{array}$ & $\begin{array}{c}\text { Sore } \\
\text { throat }\end{array}$ \\
\hline $\begin{array}{l}\text { Traumatic intubation } \\
\text { Atraumatic intubation }\end{array}$ & 56 & $4(71 \%)$ \\
\hline
\end{tabular}

Coughing and bucking might be experted to produce sore thioat also Previous investigators have not reported on this fuctor Sore throat developed almost twice as frequently in patients who had bucking episodes with the endotracheal tube 
in place (Table VII) There does appear to be a cause and effect relationship in this respect

TABLE VII

Covghing, Buciring, and Sore T'Hroat

\begin{tabular}{lcc}
\hline & $\begin{array}{c}\text { Total } \\
\text { patents }\end{array}$ & $\begin{array}{r}\text { Sore } \\
\text { throat }\end{array}$ \\
\hline $\begin{array}{l}\text { Coughing, buckng dunng anaesthesia } \\
\text { No coughing or bucking }\end{array}$ & $\begin{array}{r}173 \\
227\end{array}$ & $\begin{array}{r}14(75 \%) \\
9(40 \%)\end{array}$ \\
\hline
\end{tabular}

Topical analgesia of the larynx might be questioned as a possible cause of sore throat Conway found no difference when a topical analgesic was applied

In this study, we were surprised to find an increase in the mcidence of sore throat among the group who received topical analgesia (Table VIII) We can offer no explanation for this finding It is interesting that the incidence of sore throat was no greater when the anaesthetic was applied by the transtracheall route than when it was instilled directly into the trachea in an atraumatic manner through the larynx

TABLE VIII

Topical Anaesthetic Technique and Sore Throat

\begin{tabular}{lccc}
\hline & $\begin{array}{c}\text { Total } \\
\text { patients }\end{array}$ & $\begin{array}{c}\text { Sole } \\
\text { thrcat }\end{array}$ & \\
\hline No topical & 197 & $5(2.5 \%)$ & \\
Atomizer & 9 & $2(22,2 \%)$ & \\
Transtracheal & 28 & $2(7,1 \%)$ & $p<001$ \\
Intratracheal spray & 166 & $14(8.4 \%)$ & \\
\hline
\end{tabular}

The type of laryngoscope blade used, the amaesthetic drugs employed, the presence of oropharyngeal and nasopharyngeal arways, and the tume during which the endotracheal tube was in place were not significant factors in the evaluation The sterility of an endotiacheal tube might be thought to influence the incidence of sore throat All the tubes utilized in this study were washed in soap and water at the end of the previous operation, soaked in a disinfectant solution, and then rinsed thoroughly They were not resternlized just prior to intubation Portex and Davol plastic catheters were used The size of the endotracheal tube inserted is a difficult factor to evaluate, but in almost all patients in this senes the inflation of the cuff between the tube and the trachea was a common denominator

\section{CONCLUSIONS}

The incidence of sore throat following endotracheal intubation was sufficiently low that this technique should be employed without hesitation when indicated 
There was an increased incidence in females, in patients who had a nasogastric tube in place, in those who received topical anaesthesia, and when bucking on the tube occuried during anaesthesia

\section{SUMNIARY}

The incidence of postanaesthetic sore throat in 500 patients was determined by a method which attempted to avoid the element of suggestion

In 400 patients who were intubated, the incidence of sore throat was 57 per cent

Of 100 patients who were not intubated, two developed sore throat

Factors which may have contributed to the development of sore throat have been discussed

\section{RÉStYMÉ}

Nous avons essayé d'établır la fréquence des maux de gorge chez 500 malades en farsant des entı evues postopératorres au cours desquelles nous avons évité toute allusion à la possibilité de maux de gorge Chez 400 malades qui avarent été intubés, la fréquence des maux de gorge a été de 47 pour cent Chez 100 malades non intubés, deux ont eu mal à la gorge

La fréquence des maux de gorge a été plus élevée chez les femmes, chez les porteurs de tube naso-gastrique, chez ceux à quı on avait fait une anesthésie locale et chez ceux qui avarent fart des efforts pour expulser le tube endotrachéal

\section{REFERENCES}

1 WYLIE, W D Hazards of Intubation Anaesthesıa 5 143 (1950)

2 Baron, S H \& KoHLmoos, H W Laryngeal Sequelae of Endotracheal Anesthesia Ann Otol 60767 (1951)

3 Wolfson, B Minor Laryngeal Sequelae of Endotracheal Intubation. Brit I Anaesth 30326 (1958)

4 Conway, C , Miller, J S, \& Sagden, F L H Sore Throat after Anaesthesia Bnt J Anaesth $32 \quad 219(1960)$ 